\title{
The Irreducible Minimum
}

Over the past three decades increasing scientific attention has been directed to the problem of nosocomial infections. Investigators have surveyed epidemiologic patterns of infections, defined contributing host risk factors, and delineated virulence factors of nosocomial pathogens. Concurrently, members of hospital infection control committees have translated these and many other advances into workable policies and procedures with the goal of providing the safest possible environment for patients, hospital personnel and visitors. Despite notable successes, nosocomial infections remain a public health problem of paramount importance.

Some years ago it became apparent that physicians in the United States and clinical microbiologists in England were addressing nosocomial infection issues from complementary, but somewhat differing perspectives. In order to enrich the trans-Atlantic exchange of information, a major international pharmaceutical firm, Imperial Chemical Industries (ICI)/Stuart Pharmaceuticals, sponsored a meeting at Kings College, Cambridge in 1983. At that venue a small group of hospital epidemiologists from the US and clinical microbiologists from the UK became acquainted and began to explore the nature of the nosocomial infection problem in the two countries, along with the resources available to combat it.
The success of the meeting prompted ICI/Stuart to sponsor a follow-up meeting at the Gold Canyon Ranch, A pache Junction, Arizona, September 26-29, 1985. During this meeting the speakers were invited to address the question of "The Irreducible Minimum" risk of nosocomial infection. Could it be defined? If we have not yet achieved it, what were the scientific and practical barriers impeding its achievement? Most topics had speakers assigned from both the US and the UK. In order to further collaboration, the paired speakers were urged to communicate freely during their preparations.

It soon became evident to the participants that "the irreducible minimum" was an ideal consummately desired, but not yet achieved. Nevertheless, there was an atmosphere of tenacious optimism as the scientific and practical issues were addressed.

The Editors of Infection Control thank ICl/Stuart for its generous support and hope that the readers will find the papers and discussions stimulating in their own efforts to investigate and prevent nosocomial infections. Lastly, although the meeting was not an official function of either the Society of Hospital Epidemiologists of America (SHEA) or the Hospital Infection Society (HIS), members of both organizations took part and, it is hoped, that future collaboration between the two bodies will result.
CO-CHAIRMEN, SCIENTIFIC PROGRAM:

William Schaffner, MD

Vanderbilt University School of Medicine

Nashville, Tennessee

United States

David C. Shanson, MB, MRCPath

St. Stephen's Hospital

Chelsea, London, England

United Kingdom

\section{PARTICIPANTS:}

\section{United Kingdom}

Graham Ayliffe, The Medical School, Birmingham

Mark Casewell, King's College Hospital, London

Charles Easmon, Wright-Fleming Institute, London

Richard Lacey, University of Leeds, West Yorkshire

William Newsom, Papworth Hospital, Papworth Everard, Cambridge

William Noble, Institute of Dermatology, St. John's Hospital for

Diseases of the Skin, London

Alan Percival, Victoria University of Manchester, Manchester

Tom Rogers, Westminster Medical School, London
Philip Sanderson, Edgware General Hospital, Edgware, Middlesex Rosemary Simpson, Bristol Royal Infirmary, Bristol

David Speller, Bristol Royal Infirmary, Bristol

\section{United States}

John Burke, Latter Day Saints Hospital, Salt Lake City, Utah

Richard Dixon, Helene Fuld Medical Center, Trenton, New Jersey

Richard Garibaldi, University of Connecticut Health Center, Farmington, Connecticut

Donald Goldmann, Children's Hospital Medical Center, Boston, Massachusetts

Allen Kaiser, St. Thomas Hospital, Nashville, Tennessee

Dennis Maki, University of Wisconsin Center for Health Sciences, Madison, Wisconsin

John McGowan, Jr., Grady Memoral Hospital, Adanta, Georgia

Frank Rhame, University of Minnesota Hospitals and Clinics, Minneapolis, Minnesota

William Scheckler, University of Wisconsin Center for Health Sciences, Madison, Wisconsin

Robert Weinstein, Michael Reese Hospital and Medical Center, Chicago, Illinois

Richard Wenzel, University of Virginia Medical Center, Charlottesville, Virginia 